\title{
PENYULUHAN KEPEMIMPINAN DAN BANTUAN HUKUM BAGI MASYARAKAT MARGINAL DI DESA ANTARA
}

\author{
Rina Hayati Maulidiah, Khairun Nisa, Syahriani Sirait \\ Universitas Asahan \\ email.: rinahayati.maulidiah@gmail.com,nisakhairun2206@gmail.com. \\ syahrianisirait88@gmail.com
}

\begin{abstract}
Abstrak: Bentuk aplikasi dari serangkaian teori pendidikan yang telah dipelajari di dalam kampus tentunya akan lebih bermanfaat apabila teori-teori ilmu tersebut kita bagi kepada masyarakat. Pengabdian kepada masyarakat adalah tindakan nyata yang dapat kita lakukan untuk menambah wawasan masyarakat terhadap informasi yang akan kita bagikan, sehingga membawa kontribusi positif dalam masyarakat. Apalagi sekarang lagi hangat-hangatnya memperbincangkan tentang pemilihan kepala daerah, oleh karena itu penyuluhan tentang kepemimpinan dianggap perlu untuk di sosialisasikan kepada masyarakat. Harapan kedepannya adalah masyarakat mampu memilih pemimpin yang dapat menjadi contoh baik dalam setiap tindakan dan perkataannnya. Masyarakat diharapkan lebih hati-hati dalam memilih calon kepala daerah, tidak mudah terpengaruh citra dan kekuasaan yang dapat mendatangkan kerudian dalam masyarakat itu nantinya. Selain itu masyarakat tidak perlu takut terhadap tekanan yang mungkin saja datang untuk memaksa memilih jagoan mereka, masyarakat harus mendapatkan pencerahan tentang bagaimana hukum itu berlaku di kalangan masyarakat.
\end{abstract}

Kata kunci: Kepemimpinan, Bantuan Hukum, Masyarakat Marginal

\begin{abstract}
The application form of a series of educational theories that have been studied on campus will certainly be more useful if the theories of science are shared for the community. This activity is called our devotion to the community. As an academic both lecturers and students should be able to work together in realizing Tri Darma college where we share and gain knowledge. Community service is a real action that we can do to increase society's insight into the information we will share, thus bringing a positive contribution to society. Especially now more warmly discussed about the election of regional heads, therefore counseling about leadership is considered necessary for the socialization to the community. The future expectation is that people are able to choose leaders who can be good examples in every action and perfomance.
\end{abstract}

Keywords: Leadership, Legal Aid, Marginal Society

\section{PENDAHULUAN}

Program Kuliah Kerja Nyata tematik dan terpadu yang dilaksanakan seluruh mahasiswa universitas Asahan merupakan jawaban dari tantangan yang ada di masyarakat bagaimana dosen dan mahasiswa bekerja sama dalam menghadapi kehidupan realita di masyarakat."manusia akan lebih bermakna dan memiliki arti manakala ia hidup bersama orang lain dalam suatu tatanan kemasyarakatan."(wahyudin, 2006 : 1.6). Pesatnya perubahan dan perkembangan budaya di masyarakat, mengharuskan kita untuk terjun langsung merangkul masyarakat dalam menghadapi tantangan globalosasi dan era perdagangan bebas. Keterlibatan dosen dan mahasiswa di tengah-tengah masyarakat diharapkan dapat memberikan kontribusi positif, menumbuh kembangkan keperibadian yang mampu bersosialisasi dan memberikan solusi dari 
Vol. 1, No. 2, Jul 2018, hlm. 9 - 14

ISSN 2614-7912 (cetak)

ISSN 2622-3813 (online)

Available online at http://jurnal.stmikroyal.ac.id/index.php/jurdimas

permasalahan yang di hadapi masyarakat. Sehingga kedepannya diharapkan lulusan dari universitas asahan menjadi sumberdaya manusia yang handal, tangguh dan professional.

Pesta demokrasi menyambut pemilihan kepala daerah di kabupaten batubara akan berlangsung di bulan juni 2018. Masalah kepemimpinan menjadi perbincangan yang hangat dikalangan masyarakat kabupaten batubara khususnya di desa antara, maka dari itu penyuluhan tentang kepemimpinan adalah hal yang perlu angkat agar wawasan masyarakat tentang bagaimana memilih calon pemimpin yang tepat untuk daerahnya. Berhubungan dengan hal tersebut setelah melakukan beberapa survei di desa antara diketahui hamper 90\% masyarakat desa antara beragama islam, maka dari itu tema kepemimpinan yang diangkat adalah sosok pemimpin yang mampu membawa perubahan zaman yang penuh dengan gelap gulita menuju zaman yang berilmu dan berteknologi tinggi hingga saat ini. Menyadarkan kepada masyarakat bahwa sebelum kita memilih seorang pemimpin yang akan membawa perubahan,

Dalam diri seorang pemimpin harus memiliki karakter terutama karakter untuk membangunjati diri bangsa. Aqib (2011: 28) menyebutkan karakter dalam diri seorang pemimpin perlu dengan sengaja dibangun, dibentuk, ditempa, dan dikembangkan serta dimantapkan yang besar pengarunya terhadap lingkugan kecil seperti tempat tinggal kita, lingkungan masyarakat sekitar kita dan akan merambah pada lingkungan berbangsa dan bernegara bahkan di kehidupan global. Apabila dalam jati diri seorang pemimpin telah terbentuk karakter yang berazaskan pada tatanan nilai-nilai agama dan moral, maka dengan demikian terbentiklah jiwa kepemimpinan yang menjadi bagian dari kepribadiannya. Paham tentang konsep kepemimpinan dan siapa pemimpin itu sebenarnya.
Pertanyaannya sekarang adalah, siapa pemimpin itu? Jawabannya adalah kita semua, semua kita adalah pemimpin sebagaimana sabda Nabi dalam sebuah haditsnya yang bersumber dari Ibnu Umar dan Sayyidah Aisyah sebagai berikut:

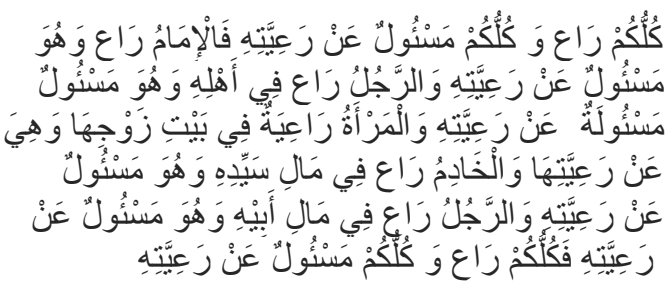

Artinya: "Masing-masing kalian adalah pemimpin dan akan ditanya tentang kepemimpinannya. Seorang imam (kepala negara) adalah pemimpin dan akan ditanyai tentang kepemimpinannya. Seorang laki-laki adalah pemimpin dalam keluarganya dan akan ditanyai tentang kepemimpinannya. Setiap perempuan adalah pemimpin di rumah suaminya dan akan ditanyai tentang kepemimpinannya. Setiap asisten rumah tangga adalah pemimpin pada harta majikannya dan akan ditanyai tentang kepemimpinannya. Setiap laki-laki juga pemimpin pada harta orangtuanya dan akan ditanya tentang kepemimpinannya. Setiap kalian adalah pemimpin dan akan ditanya tentang kepemimpinannya. (HR al-Bukhari dan Muslim). Hazzel (2007) Kepemimpinan dapat juga diartikan sebagai proses memengaruhi atau memberi contoh oleh pemimpin kepada pengikutnya dalam upaya mencapai tujuan organisasi. Kepemimpinan merupakan proses mempengaruhi aktivitas kelompok dalam rangka perumusan dan pencapaian tujuan. Kepemimpinan berasal dari kata pemimpin. Pengertian pemimpin adalah suatu peran atau ketua dalam sistem di suatu organisasi atua kelompok. Sedangkan kepemiminan merupakan kemampuan yang dimiliki seseorang untuk memengaruhi orang-orang untuk bekerja mencapai tujuan dan sasaran.

Bantuan hukum bagi masyarakat marginal dimaksudkan untuk memberikan 
Vol. 1, No. 2, Jul 2018, hlm. 9 - 14

ISSN 2614-7912 (cetak)

ISSN 2622-3813 (online)

Available online at http://jurnal.stmikroyal.ac.id/index.php/jurdimas

wawasan pada masyarakat secara umum tentang betapa pentingnya kita sebagai masyarakat paham akan hukum yang berlangsung dilingkungan sekitar kita. Pramoediya (2016) "bantuan hukum merupakan jasa hukum yang khusus diberikan kepada fakir miskin yang memerlukan pembelaan secara cumacuma, baik di luar maupun di dalam pengadilan, secara pidana, perdata, dan tata usaha negara, dari seseorang yang mengerti seluk beluk pembelaan hukum, asas-asas dan kaidah hukum, serta hak asasi manusia". Diharapkan dengan adanya penyuluhan tentang bantuan hukum bagi masyarakat marginal ini, masyarakat tidak tabu lagi dan paham apa yang harus dilakukan apabila mengalami musibah yang mengharuskan tindakan hukum diberlakukan.

\section{METODE}

Terselenggaranya penyuluhan tentang kepemimpinan dan bantuan hukum bagi masyarakat marginal adalah sebagai bukti keberhasilan kolaborasi antara dosen, mahasiswa dan masyarakat. Eratnya hubungan sosial yang terjalin selama pengabdian terbukti dengan antusias masyarakat dalam mengikuti penyuluhan tersebut. Sambutan baik kepala desan dan segenap warga desa dalam pelaksanaan penyuluhan tersebut membuktikan bahwa masyarakat butuh informasi yang menambah wawasan dan pemahaman tentang tema yang disampaikan dalam penyuluhan tersebut.

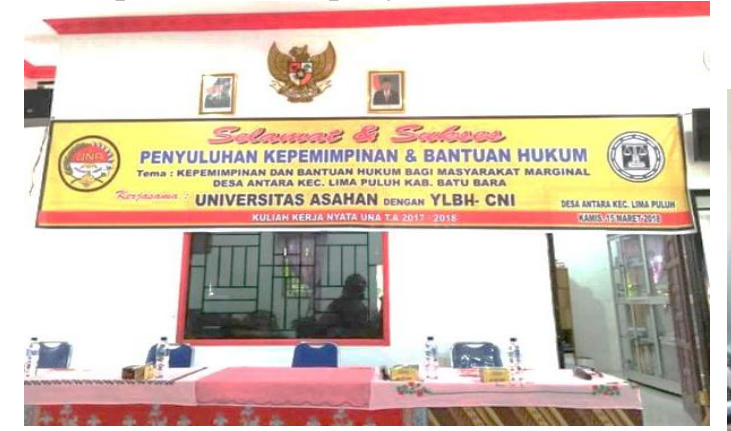

Gambar 1. Persiapan Penyuluhan di desa antara
Setiap kegiatan yang dilaksanakan tentunya bukanlah suatu hal yang tidak terencana, melainkan sebuah program kegiatan yang sudah terjadwal sedemikian rupa sehingga pada saat melakukan survey lapangan mengumpulkan informasi apa-apa saja yang dibutuhkan masyarakat dalam jangka pendek dan jangka panjang. Setelah melakukan beberapa kali kunjungan dan atas izin dari kepala desa setempat akhirnya pengabdian kepada masyarakat ini dapat terujud, dengan memilih tema yang memang sedang hanyat diperbincangkan pada masa itu.

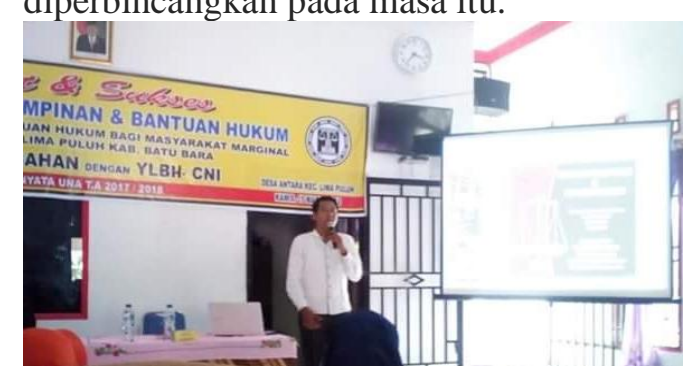

Gambar 2. Penyampaian Materi

Kepemimpinan dan Bantuan Hukun

Pengabdian kepada masyarakat ini dilaksanakan pada hari kamis tanggal 15 Maret 2018 tepatnya di desa antara kabupaten batubara, yang memang beberapa bulan kedepan tepatnya bulan juni akan melakukan pemungutan suara menentukan hak pilih setiap warga desanya untuk memilih kepala daerah mereka selama lima tahun kedepan. Mudah-mudahan dengan adanya penyuluhan tentang kepemimpinan dan bantuan hukum bagi masyarakat marginal ini bias menjadi tolak ukur masyarakat dalam menentukan pilihannya.

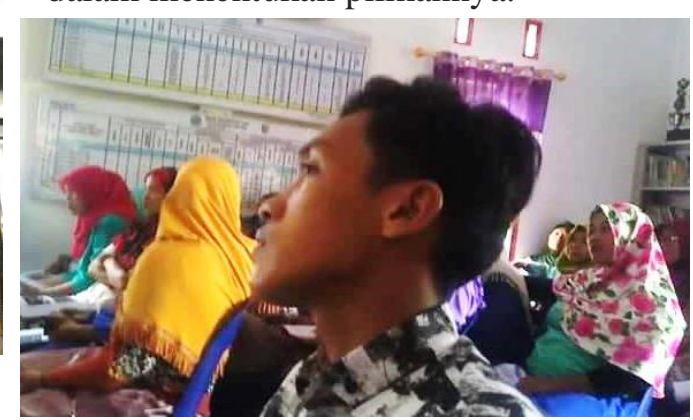


Vol. 1, No. 2, Jul 2018, hlm. 9 - 14

ISSN 2614-7912 (cetak)

ISSN 2622-3813 (online)

Available online at http://jurnal.stmikroyal.ac.id/index.php/jurdimas

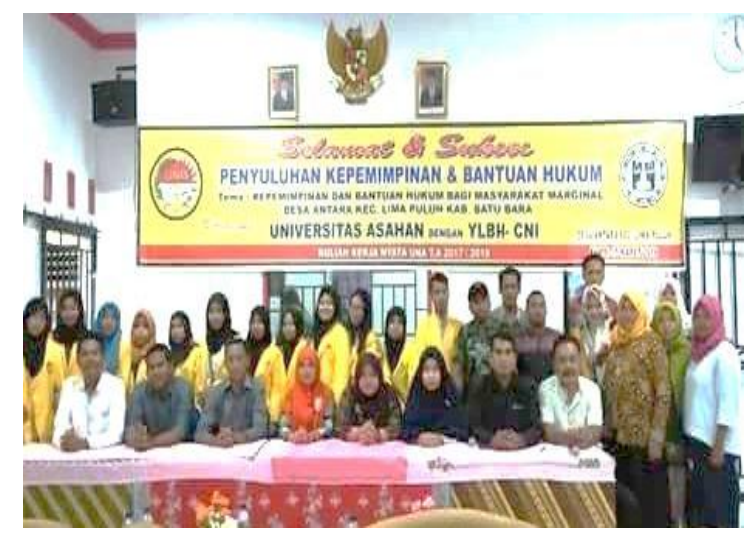

Gambar 3. Pembicara dan peserta penyuluhan Kepemimpinan dan Bantua Hukum

\section{PEMBAHASAN}

Membentu jati diri seorang pemimpin bukanlah suatu perkara yang mudah, namun dapat bentuk melaui pengawasan dan pembinaan prilaku menuju pada konsep nilai kepribadian seperti pendalaman nilai agama dan nilai moral. Sehingga terjadi keselarasan akidah dalam tatanan kehidupan social bermasyarakat. Pada hakekatnya manusia di muka bumi ini adalah pemimpin, maka dari itu pendidikan yang terencana akan membentuk karakter yang diinginkan. Seperti pendidikan di bangku sekolah. Pendidikan di sekolah telah dirancang sedemikian rupa untuk membentuk jati diri anak bangsa pada karakter yang telah di programkan, Prayitno (2011: 171) menjelaskan bahwa dalam pendidikan itulah, mulainya proses pembelajaran yang diselenggarakan, dididik dan diajarkan untuk mengembangkan berbagai keterampilan dan kompetensi dan juga niali-nilai karakter cerdas. secara sederhana sebagaimana manusia itu mampu memimpin dirinya sendiri terlebih dahulu, sehingga kelak mampu memimpin dalam sebuah masyarakat luas. terdapat beberapa konsep kepemimpinan yang dilakukan Nabi yang dapat kita jadikan acuan/contoh, diantaranya adalah;

1. Nabi selalu menyesuaikan teori kepemimpinan yang beliau sampaikan dengan tindak-tanduknya sehari-hari. Perkataan yang disampaikan harus sesuai dengan semua bentuk tindakan yang dilakukan. Janji-janji yang disampaikan pada saat kampenye pemilihan kepada masyarakat merupakan bentuk ikrar perkataan calon pemimpin dengan masyarakatnya. Maka pada saat calon pemimpin tersebut terpilih menjadi pemimpin suatu daerah tertentu harus menepati janji yang sudah disampaikannya tersebut. Dengan demikian pemimpin tersebut sudah melaksanakan konsep kepemimpinan Nabi pada poin yang tertama.

2. Nabi selalu memutuskan semua perkara yang beliau hadapi dengan jalan musyawarah dan mufakat. Konsep kepemimpinan Nabi pada poin yang kedua ini menjelaskan bahwa sebagai seorang pemimpin kita tidak boleh mengambil keputusan berdasarkan keinginan sendiri, mementingkan kepentingan sendiri. Hendaklah segala sesuatunya diselesaikan secara duduk bersama bermusyawarah dalam mencapai kemufakatan, tanpa memandang jabatan, ras dan golongan, setiap perbedaan pendapat merupakan rahmad yang Allah karuniakan kepada hambanya.

Kedua konsep kepemimpinan Nabi di atas menjelaskan secara umum kreteria sosok pemimpin yang dapat kita jadikan contoh. Pilihlah sosok pemimpin yang berani dan hanya takut kepada Allah SWT saja. Konsep kepemimpinan tersebut sangat sesuai dengan masyarakat Indonesia yang mencintai kedamaian dan keramah-tamahan serta menjunjung tinggi nilai-nilai kenagsaan, suku, agama dan bahasa. Danarto (2001: 121) bangsa Indonesia adalah bangsa yang sederhana jati dirinya.Seperti halnya Nabi dalam menentukan calon pemimpin memiliki 
Vol. 1, No. 2, Jul 2018, hlm. 9 - 14

Available online at http://jurnal.stmikroyal.ac.id/index.php/jurdimas

enam prinsip kepemimpinan, diantaranya adalah;

1. Beliau menomorsatukan fungsi sebagai landasan dalam memilih orang atau sesuatu, bukan penampilan atau faktor-faktor luar lainnya. Pemimpin yang tau apa yang harus dilakukan memahami makna dan fungsi seorang pemimpin. Sehingga pemimpin tersebut mampu menjalankan roda kepemerintahan dengan benar tanpa ada tekanan dari pihak manapun,

2. Beliau mengutamakan segi kemanfaatan daripada kesia-siaan. menyerahkan urusan kepemerintahan dengan memilih orang-orang yang ahli dibidangnya bukan dari penampilannya.

3. Beliau mendahulukan yang lebih mendesak daripada yang bisa ditunda. Hal ini tentunya menjadi pelajaran kepada kita untuk selalu mendahulukan kepentingan yang lebih mendesak, dan menunda kepentingan yang dianggap kurang mendesak, sehingga pencapaikan kinerja dapat terlaksana dengan cepat dan terorganisir dengan baik.

4. Beliau lebih mementingkan orang lain daripada dirinya sendiri. Sudah selayaknya seorang pemimpin lebih mementikan kepentingan umum dari pada kepentingan pribadinya. Mendahulukan kepentingan orang banyak adalah bentuk toleransi, loyalitas dan lebih memihak kepada kesejahteraan rakyat sehingga roda kepemerintahannya dapat berjalan dengan seimbang.

5. Beliau memilih jalan yang tersukar untuk dirinya dan termudah untuk umatnya. Konsep ini tentulah berat namun sebagai seorang pemimpin harus berada digarda terdepan untuk menjadi teladan bagi masyarakatnya, di garda tengah membangkitkan niat perubahan yang positif dengan karya-karya yang inovatif, dan di garda belakang memberi penye- mangat untuk terus memotivasi agar masyarakatnya lebih baik lagi, lagi dan lagi.

6. Beliau lebih mendahulukan tujuan akhirat daripada maksud duniawi. Pemimpin yang hanya memiliki tujuan akhirat tentulah sosok pemimpin yang hanya takut kepada Allah SWT, sehingga korupsi kolusi dan nepotisme bukanlah ambisinya sebagai seorang pemimpin, melainkan ridha Allah SWT sajalah yang diharapkan dari kepemimpinannya.

Menjadi seorang pemimpin bukanlah hal mudah namun bila kita melaksanakan keenam prinsip kepemimpinan di atas akan mejadikan kita seorang pemimpin yang kuat, disegani dan bermartabat. Bukan hanya sekedar pencitraan yang menipu masyarakat. Diharapkan seluruh masyarakat desa antara menjadi masyarakat yang kuat, disegani dan bermartabat. Jangan sampai salah memilih pemimpin Djohan (2004: 20) bahwa orang yang tidak dapat dijadikan pemimpin adalah orang yang tidak pandai mengatur diri, pencitraan yang menipu rakyat, kurang pertimbangan dan banyak berbohong.

Sebagai masyarakat kita bebas memilih calon pemimpin tanpa merasa tertekan atau terintimidasi dari pihak lain. Keresahan masyarakat terhadap pemimin yang tidak bijaksana tercermin dari ketidak tahuan mereka terhadap hukum, sehingga masyarakat sering dimanfaatkan oleh oknum pemerintah yang tidak bertanggung jawab. Universitas Asahan bekerja sama dengan YLBHI-CNI untuk memberikan informasi seputar hukum yang sering dihadapi masyarakat umum. Apa kewajiban yang harus dipatuhi masyarakat bila mengalami musibah yang berkaitan dengan ranah hukum, apa-apa saja tindakan yang harus dilakukan didalam menghadapi persoalan tersebut. Masyarakat juga diarahkan bagaimana menghadapi berbagai situasi dan kemana harus melapor atau membuat pengaduan 
Vol. 1, No. 2, Jul 2018, hlm. 9 - 14

ISSN 2614-7912 (cetak)

ISSN 2622-3813 (online)

Available online at http://jurnal.stmikroyal.ac.id/index.php/jurdimas

apa bila ingin mendapatkan pembelaan atau mendapatkan keadilan dari permasalahan hukum yang tengah di hadapi.

\section{UCAPAN TERIMA KASIH}

Ucapan terikma kasih sebesarbesarnya kepada Kepada Kepala Desa Antara yang telah mengizinkan dan membantu bagi terselenggaranya penyuluhan kepemimpinan dan bantuan hukum, dan seluruh masyarakat desa antara yang telah hadir untuk mengikuti penyuluhan tersebut, sebuah kegiatan tanpa peserta adalah sia-sia. Ucapan terima kasih kepada dosen dan mahasiswa yang telah membantu dari segi moril dan materil, dan ucapan terima kasih setinggiyingginya kepada pembicara baik dari pihak Universitas Asahan dan Yayasa Lembaga Bantuan Hukum Cakrawala Nusantara Indonesia (YLBU-CNI)

\section{SIMPULAN}

Sebagai masyarakat kita bebas memilih calon pemimpin tanpa merasa tertekan atau terintimidasi dari pihak lain. Keresahan masyarakat terhadap pemimin yang tidak bijaksana tercermin dari ketidak tahuan mereka terhadap hukum, sehingga masyarakat sering dimanfaatkan oleh oknum pemerintah yang tidak bertanggung jawab. Universitas Asahan bekerja sama dengan YLBHI-CNI untuk memberikan informasi seputar hukum yang sering dihadapi masyarakat umum. Apa kewajiban yang harus dipatuhi masyarakat bila mengalami musibah yang berkaitan dengan ranah hukum, apa-apa saja tindakan yang harus dilakukan didalam menghadapi persoalan tersebut. Masyarakat juga diarahkan bagaimana menghadapi berbagai situasi dan kemana harus melapor atau membuat pengaduan apa bila ingin mendapatkan pembelaan atau mendapatkan keadilan dari permasalahan hukum yang tengah di hadapi.

\section{DAFTAR PUSTAKA}

Wahyudin, Dinn. Supriadi. Abduhak, Ishak. 2006. Pengantar Pendidikan. Jakarta: universitas Terbuka.

Nogi, Hessel. 2007. Manajemen Publik. Jakarta: PT Grasindo Aqib, Zainal. 2011. Pendidikan Karakter Membangun Prilaku Positif Anak Bangsa. Bandung: Yrama Widya.

Prayitno. Manullang, Belferik. (2011). Pendidikan Karakter dalam Pembangunan Bangsa. Jakarta: Grasindo.

Darnato, dkk. (2001). Sederhana Itu Indah. Jakarta: Republika.

Djohan, Djamalus. 2004. Nasehat OrangOorang Pintar di Dunia. Jakarta: Pustaka Al Husna Baru.

https://pramudyarum.wordpress.com/2016 /06/07/bantuan-hukum-bagimasyarakat-miskin/

https://www.google.com/search?source=h p\&ei=FcReW8bcMsL28AWws7u YAw\&q=ingarso+sung+tulodo\&oq =ingarso\&gs_l=psy

http://madinahsyariahsupermarket.blogsp ot.com/2009/11/6-prinsipkepemimpinan-nabimuhammad.html

http://www.nu.or.id/post/read/85336/kons ep-kepemimpinan-nabi-muhammad 